\title{
A stable isotope study of organic cycling and the ecology of an anchialine cave ecosystem
}

\author{
John W. Pohlman ${ }^{1, *}$, Thomas M. Ilifife ${ }^{2}$, Luis A. Cifuentes ${ }^{1}$ \\ ${ }^{1}$ Department of Oceanography, Texas A\&M University, College Station, Texas 77845, USA \\ ${ }^{2}$ Department of Marine Biology, Texas A\&M University at Galveston, Galveston, Texas 77553-1675, USA
}

\begin{abstract}
Stable carbon and nitrogen isotope data, complemented with other geochemical parameters, were used to identify the sources of organic matter that support the food web of an anchialine cave ecosystem in the northeastern Yucatan Peninsula, Mexico. Anchialine caves, common along tropical karstıc and volcanic coastlines, are completely or partıally inundated by highly stratified layers of fresh and marine waters. Stable isotope data from the cave fauna, the particulate organic matter (POM) from the cenote pool and from the cave, the forest soil and the cave sediments indicated that at least 3 sources of nutritive organics could support the anchialine food web. These sources were: (1) soil from the overlying forest; (2) freshwater algae from adjoining open water pools; and (3) chemoautotrophic nitrifying bacteria living in the cave. Production of nitrate and a decrease in $\mathrm{O}_{2}$ along the halocline provided geochemical evidence of nitrification. Stable nitrogen isotope data defined 2 to 2.5 trophic levels in the food web. Furthermore, it was found that troglobitic (cave-limited) species residing in the water column are capable of preferentially feeding on specific organic reservoirs. This study presents the first extensive description of the ecological and biogeochemical relationships of the anchialine cave ecosystem.
\end{abstract}

KEY WORDS: Anchialune Organıc cycling Nitrification - Niche partitioning Yucatan Penınsula . Cave

\section{INTRODUCTION}

In many tropical karstic regions, coastal groundwater consists of a fresh to slightly brackish lens overlying seawater that intrudes from the coast (Iliffe 1992a). Within these 'underground estuaries' in areas such as the Yucatan Peninsula of Mexico, vast cave networks, technically termed anchialine, meander through the Pleistocene bedrock (Back et al. 1979). Mixing of the water masses at the halocline produces a corrosive solution capable of dissolving additional limestone (Back et al. 1986) (Fig. 1a). The dissolution of limestone under such conditions has created extensive cave systems that serve as conduits for groundwater flow and provide habitat for a unique community of troglobitic (cave-limited) organisms.

\footnotetext{
- Present address: Geo-centers lnc., 10903 Indian Head Highway, Fort Washington, Maryland 20744, USA

E-mail: johnp@ccf.nrl.navy.mil
}

The recognition of anchialine caves as a significant biological habitat has only occurred over the past 2 decades. Developments in diving technology have made it possible for trained cave-diving scientists to investigate the biology of the anchialine habitat. Consequently, our knowledge of the taxonomy and biogeography of troglobitic organisms in anchialine caves has increased tremendously (Yager 1981, Iliffe 1983, Iliffe et al. 1984b, Bowman et al. 1985, Hart et al. 1985. Manning et al. 1986). These discoveries have provided the foundation for the investigation of anchialine cave ecology and biogeochemistry: the focus of the present study.

The world's most extensive anchialine cave networks are found in the Yucatan Peninsula of Mexico, a flat limestone plain completely devoid of surface rivers and streams. Due to this absence of surface streams, the underground aquifer is the primary reservoir for domestic, agricultural and industrial needs. This water is accessible principally through pools called cenotes 


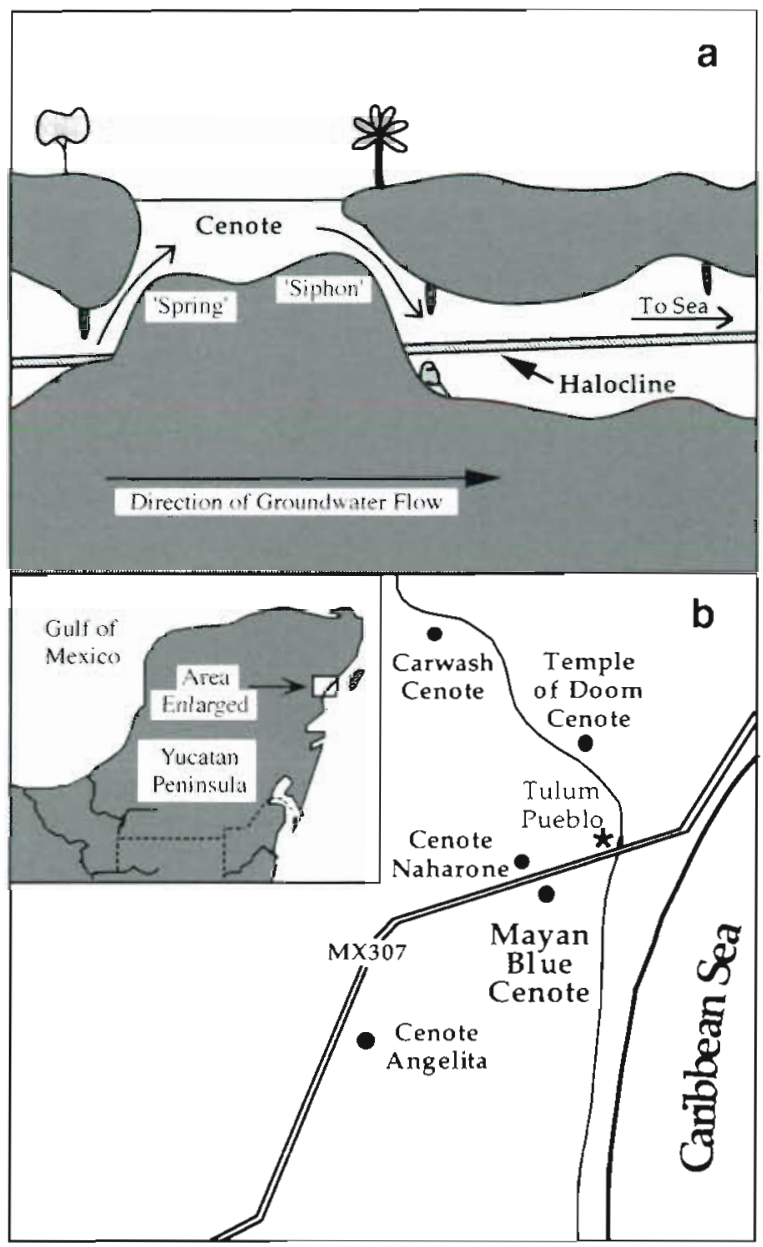

Fig. 1 (a) Schematic diagram of a typical cenote-cave system. Cave passages are primarily formed by mixing corrosion at the depth of the halocline, while cenotes result from the collapse of the ceiling. The caves serve as conduits for the groundwater flowing to the coast. Typically, water emerges from a spring on one side of the cenote pool and returns below ground through a siphon on the opposite side. (b) Map of the Yucatan Peninsula (Mexico) showing the location of Mayan Blue Cenote relative to several other sites

that pockmark the karst landscape of the peninsula and wells bored into the limestone caprock (Back \& Hanshaw 1974).

At the present time, this coastal aquifer is pristine, but as the population and economy continue to grow, the groundwater quality will likely be compromised. Injection of wastewater or sewage into the groundwater is a primary concern. Dissolved oxygen (DO) levels in groundwater are inherently low due to the absence of photosynthesis in the aphotic subterranean environment and isolation from atmospheric exchange (Iliffe et al. 1984a). Increasing the input of organic material stimulates bacterial productivity and respiration, further depleting DO and producing zones of anoxia spreading out from the source of contamination. For example, Iliffe et al. (1984a) investigated Government Quarry Cave, an anchialine cave in Bermuda, to assess the damage caused by such organic pollution. Domestic wastes dumped into the cave pool caused widespread anoxia, eradication of the macrofauna and high accumulations of nutrients. According to their calculations, doubling the natural input of organic matter into such caves can result in anoxic conditions. Considering the small quantities of organic material naturally present in anchialine caves (Fichez 1991), doubling the size of the organic matter reservoir is not difficult to do.

Most aquatic cave ecosystems are regarded as detritus-based (Dickson 1975), but chemoautotrophic primary production has been documented in several caves. The ecosystem in Movile Cave, a thermomineral cave in Romania, is supported entirely by chemoautotrophic sulfide-oxidizing bacteria floating at the water's surface in air pockets and coating the walls of the underwater cave (Sarbu et al. 1996). Dissolved $\mathrm{H}_{2} \mathrm{~S}$ concentrations supporting this production are exceptionally high, ranging between 500 and $1300 \mu \mathrm{M}$. Additionally, several submarine caves in Italy receive input from warm sulfurous springs and have associated chemoautotrophic bacterial mats (Southward et al. 1996). Stable carbon isotope ratios of animal tissue from that study indicated that the bacterial contribution to the food chain varies with species from 0 to $100 \%$. Because anchialine caves are not typically associated with geothermal sources, we inferred that their ecology would be governed by different biogeochemical principles.

We hypothesized that the major reservoirs of organic matter supporting the anchialine ecosystem would be: (1) algal detritus transported by groundwater flow from the cenotes; (2) soil particulates percolating from the tropical forest soil through the cracks and fissures of the limestone bedrock into the caves; and (3) coastal-borne particulate organic matter (POM) transported into the cave systems with tidally exchanged seawater. We also expected that algal and soil detritus would support the community above the halocline, while the coastal-borne POM would nourish the community below the halocline. We recognized the potential for chemoautrophic production of organic material by methane, hydrogen sulfide or regenerated ammonia, but assumed it would be insignificant in terms of its contribution to the nutritive organic pool.

\section{MATERIALS AND METHODS}

Study site and collection procedures. The study site was in and around Mayan Blue Cenote, a karst window in the Systema Naranjal anchialine network. 
Mexico (Fig. 1b). The orientation of the $18.47 \mathrm{~km}$ long Systema Naranjal is perpendicular to and about $5 \mathrm{~km}$ inland from the Caribbean coast (J. Coke pers. comm.). Samples were collected during expeditions in July 1993. March and August 1994, and March 1995. The samples collected included fauna, flora, sediments, POM, bacteria and water from the caves and open water cenote pools, as well as vegetation and soil from the tropical forest. Fauna were either collected individually in plastic vials or with a diver-towed $0.3 \mathrm{~m}$ diameter plankton net with a $93 \mu \mathrm{m}$ mesh. The fauna were collected from 5 different passages accessed from Mayan Blue Cenote (Pohlman 1995). Sediments, soil, bacteria and flora were collected in sterile Whirl-Pak plastic sacs, while POM samples were collected with a diver-operated Wilden M.025 pneumatic pump onto precombusted Whatman GF/F filters. Water samples were collected in $50 \mathrm{ml}$ Nalgene bottles that were acid cleaned and filled with distilled water before the dive. Water samples collected for $\delta^{13} \mathrm{C}$-DIC (dissolved inorganic carbon) and DIC concentration analyses were fixed with a saturated $\mathrm{HgCl}_{2}$ solution immediately after the dive. Scientifically trained cave divers, following standards set by the National Speleological Society-Cave Diving Section (NSS-CDS), collected all samples.

Troglobitic fauna. A diverse and unique assemblage of troglobitic fauna have been identified from the caves surrounding Mayan Bhe Cenote. The freshwater lens above the halocline is habitat for 1 species of fish and 6 species of Crustacea, while the seawater portion of the cave supports 4 species of Crustacea (Kornicker \& Iliffe 1989, Iliffe 1992b, L. Kornicker pers. comm.). The benthic fauna includes 2 species of Isopoda (Iliffe 1992b). However, because several of these species are either rare and/or small they were not collected during this study. The species collected from Mayan Blue are listed in Table 2 (see 'Results') with habitat information and stable isotope data. The fauna were identified to the most specific taxonomic level possible-usually species.

Stable isotopes. Fauna, flora, POM, sediments and soils collected for stable isotope analysis were stored either on dry ice or in an L-C Lab Line drying oven held between 60 and $70^{\circ} \mathrm{C}$. In the laboratory, these samples were acidified to remove inorganic carbon. The samples were analyzed by a modified Dumas combustion method that converts organic carbon and nitrogen to $\mathrm{CO}_{2}$ and $\mathrm{N}_{2}$ for mass spectral analysis (Macko 1981). The nitrogen gas was analyzed on a Nuclide 3-60-RMS isotope ratio mass spectrometer and the $\mathrm{CO}_{2}$ gas by a Finnigan MAT 251 or 252 stable isotope mass spectrometer.

For $\delta^{13} \mathrm{DIC}$ analysis, the $\mathrm{CO}_{2}$ was removed from solution with $85 \%$ o-phosphoric acid and separated on a
Varian 3400 Gas Chromatograph (GC). The GC was coupled to a combustion oven and a Finnigan MAT 252 stable isotope mass spectrometer, where the $\mathrm{CO}_{2}$ was analyzed.

Stable carbon and nitrogen isotope ratios are reported according to the standard formula:

$$
\delta X=\left\{\left(R_{\text {sample }} / R_{\text {standard }}\right)-1\right] \times 10^{3} \%
$$

where $\delta X$ is either $\delta^{13} \mathrm{C}$ or $\delta^{15} \mathrm{~N}$, and $R$ is either ${ }^{13} \mathrm{C} /{ }^{12} \mathrm{C}$ or ${ }^{15} \mathrm{~N} /{ }^{14} \mathrm{~N}$. The standards for carbon and nitrogen are, respectively, PeeDee Belemnite limestone fossil and atmospheric dinitrogen gas. The precision for both instruments was $\pm 0.2 \%$.

Dissolved inorganic carbon. DIC concentrations were measured coulometrically (Dickson \& Goyet 1991). Triplicate samples $(10 \mathrm{ml})$ were injected into a stripping chamber containing $0.1 \mathrm{~N} \mathrm{H}_{2} \mathrm{SO}_{4}$ that converted the $\mathrm{DIC}$ to $\mathrm{CO}_{2}$. The evolved $\mathrm{CO}_{2}$ entered a coulometer cell (UIC Inc., Model 5011) where it was titrated to a constant endpoint. The integrated titration current measured by the coulometer was converted to $\mu \mathrm{M} \mathrm{CO}_{2}$. Precision of standards prepared from $\mathrm{NaCO}_{3}$ was $\pm 2.8 \mu \mathrm{M}$.

Dissolved inorganic nitrogen (DIN), methane and total dissolved sulfide (TDS). $\mathrm{DIN}\left(\mathrm{NO}_{3}^{-}, \mathrm{NO}_{2}{ }^{-}\right.$and $\mathrm{NH}_{4}{ }^{+}$) was measured on a Technicon AA-II Autoanalyzer (Koroleff 1970, Aminot \& Kerovel 1982). Methane was measured by the headspace phase equilibrium method with a Shimadzu gas chromatograph equipped with a flame ionization detector (McAuliffe 1971). TDS was determined spectrophotometrically in the field against a standard curve generated by the Cline (1969) method. Sensitivity range for the curve was between 2 and $40 \mu \mathrm{M}$. Because of the lack of laboratory facilities in the field, the standard curve was generated $1 \mathrm{wk}$ prior to the field work.

Organic carbon and nitrogen analysis. Sediments and algae collected from the pool and cave were analyzed for percent organic carbon and nitrogen. Sample preparation was conducted according to the methods described by Nieuwenhuize et al. (1994) and the analysis carried out with a Carlo Erba NA-1500 elemental analyzer. This technique is particularly useful for analyzing carbonate-rich sediments like those found in the caves

Multiprobe parameters. Salinity, temperature, $\mathrm{pH}$ and DO were measured with a Hydrolab Datasonde III multiprobe. Accuracy was $\pm 0.2 \mathrm{~g} \mathrm{l}^{-1}$ for the salinity, $\pm 0.15^{\circ} \mathrm{C}$ for the temperature, \pm 0.02 units for $\mathrm{pH}$ and $\pm 0.2 \mathrm{mg} \mathrm{l}^{-1}$ for DO. The probe was equipped with an independent battery pack and data logger which made it possible to transport the probe into the underwater cave for profiling. The unit was carried by the first diver with the probes leading to avoid measuring an artificially mixed water column. 

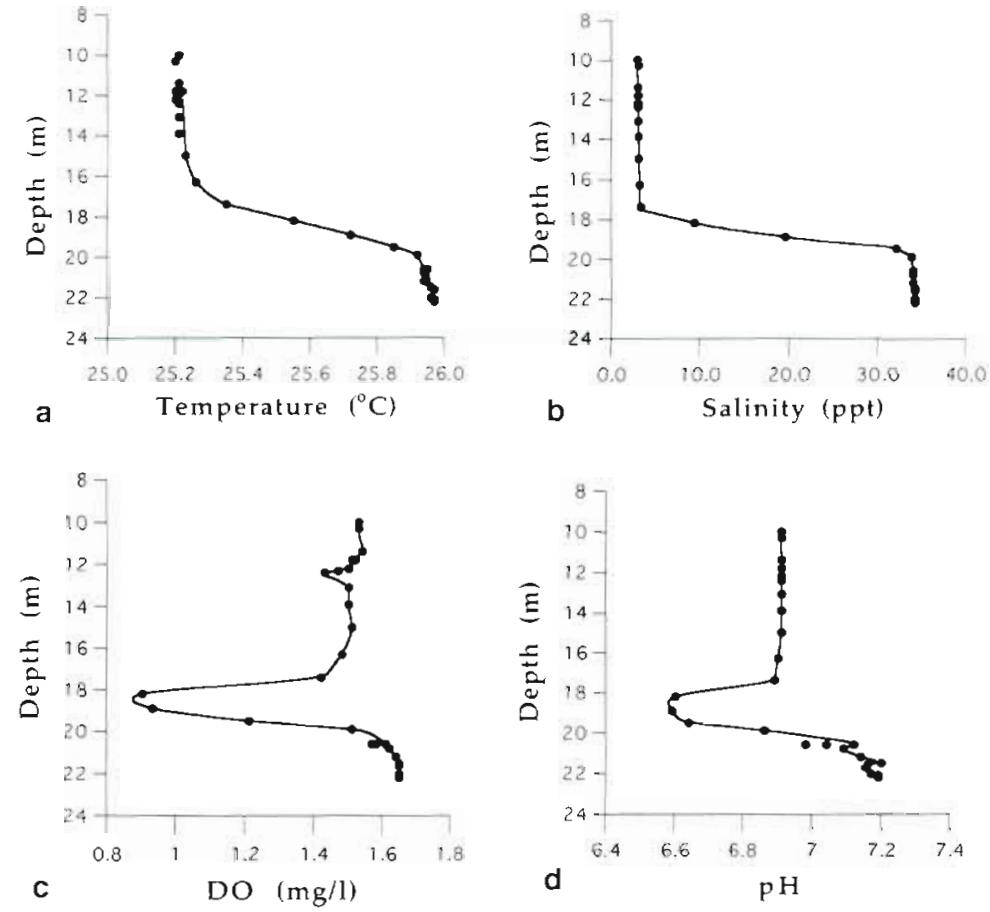

Fig. 2. Vertical profiles of (a) temperature, (b) salinity, (c) dissolved oxygen (DO) and (d) pH from Mayan Blue cave system, March 1995

\section{RESULTS}

\section{Physical properties of the water column}

Temperature and salinity profiles from a Mayan Blue cave passage illustrate the sharp division between the brackish and seawater components of the water column (Fig 2). Over a $3 \mathrm{~m}$ vertical range the salinity changed from $3.2 \mathrm{~g} \mathrm{I}^{-1}$ to a nearly full seawater concentration of $34.3 \mathrm{~g} \mathrm{l}^{-1}$ The temperature of the 2 water masses differed by $0.8^{\circ} \mathrm{C}$, with the deeper seawater being slightly warmer at $26^{\circ} \mathrm{C}$. Non-conservative mixing between temperature and salinity indicated that water has cooled slightly since entering the groundwater (Fig. 3a)

\section{Biogeochemical properties of the water column}

Constituents of the water column affected by biogeochemical activity also showed dramatic variations in the halocline. DIC concentrations were much higher in the brackish region of the water column with a maximum of $8.01 \mathrm{mM}$ near the cave ceiling at a depth of $10 \mathrm{~m}$ (Fig. 4a). Below the halocline, DIC varied between 2.16 and $2.70 \mathrm{mM}$. The stable carbon isotope values of DIC $\left(\delta^{13} \mathrm{DIC}\right)$ also reflected a mixing of 2 distinct water types as $\delta^{13} \mathrm{DIC}$ values as negative as $-15.0 \%$ near the cave ceiling increased to $-3.0 \%$ at the cave floor (Fig $4 \mathrm{~b}$ ). The most dramatic changes of $\delta^{13} \mathrm{DIC}$ occurred in the halocline.

DIN concentrations were similar above and below the halocline, but displayed unexpected behavior within the halocine (Fig. 5). Ammonium $\left(\mathrm{NH}_{4}{ }^{+}\right)$concentrations were consistently low, ranging between 0 and $0.02 \mu \mathrm{M}$. Nitrite $\left(\mathrm{NO}_{2}{ }^{-}\right)$concentrations ranged between 0.02 and $0.07 \mu \mathrm{M}$ above and below the halocline, but displayed a $0.70 \mu \mathrm{M}$ peak within it. Nitrate $\left(\mathrm{NO}_{3}{ }^{-}\right)$was most abundant, varying between 2.92 and $5.79 \mu \mathrm{M}$ above and below the halocline, but showed a pronounced peak increasing from 6.32 to $18.64 \mu \mathrm{M}$ in the halocline. Although this is a 1 point peak, a similar nitrate peak of $23 \mu \mathrm{M}$ measured by Stoessell et al. (1989) at the depth of the halocline corroborates the $18.64 \mu \mathrm{M}$ nitrate peak measured during this study.

Near hypoxic conditions existed throughout the water column with dissolved oxygen (DO) values ranging between 1.4 and $1.7 \mathrm{mg} \mathrm{l}^{-1}$ in water masses above and below the halocline (Fig. 2c) In the mixing zone of
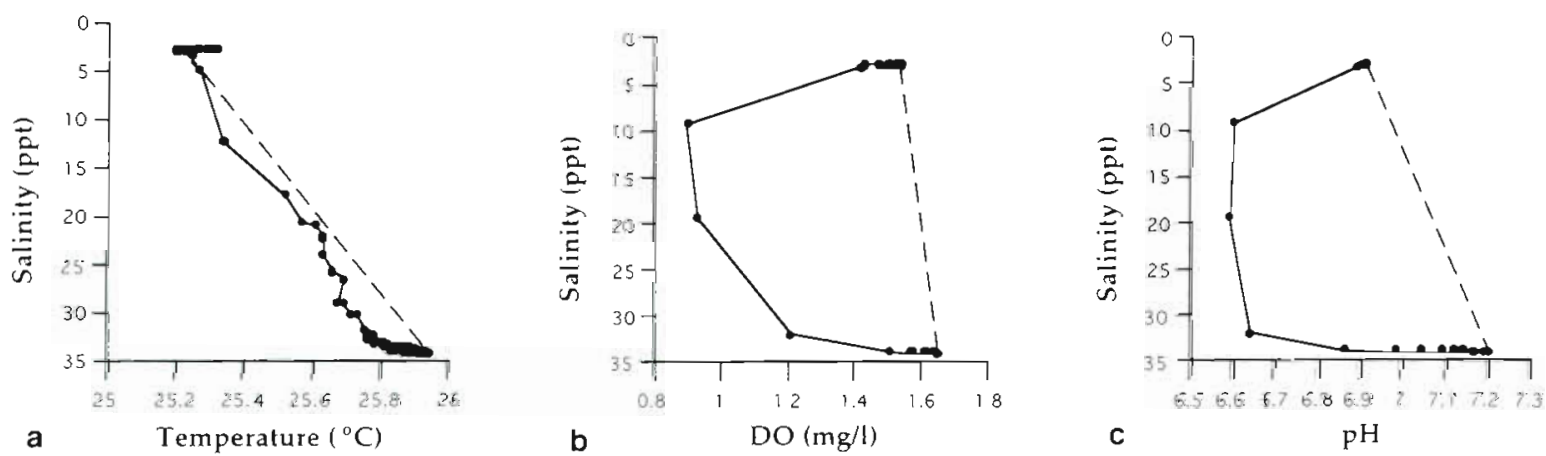

Fig. 3. Property salinity plots for (a) temperature, (b) dissolved oxygen (DO) and (c) pH from Mayan Blue cave system, March 1995. Dashed lines between salinty end members represents the conservative mixing distribution 


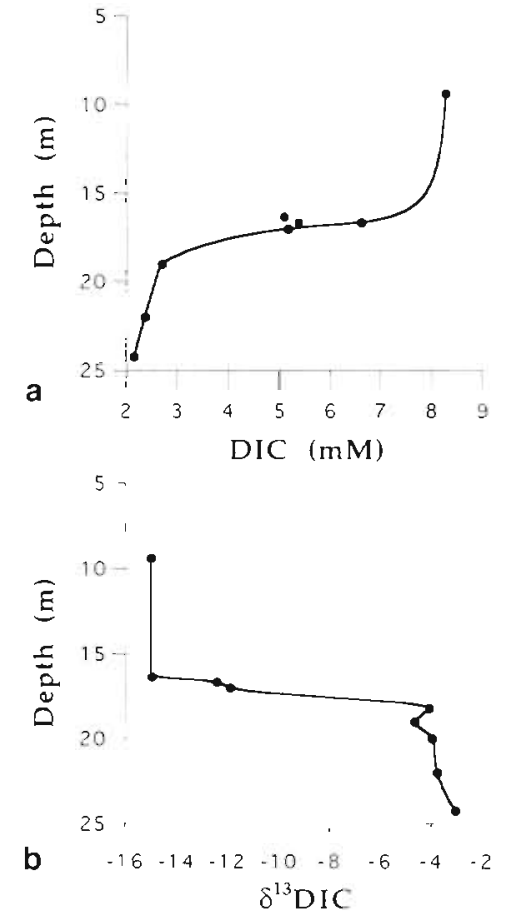

Fig 4. Vertical profiles of (a) dissolved inorganic carbon (DlC) concentration and (b) DIC stable carbon isotope ratios from Mayan Blue cave system, March 1995. Property changes occurred in the halocline

the halocline, however, there was a decrease in the amount of DO as concentrations dropped as low as $0.9 \mathrm{mg} \mathrm{l}^{-1}$ DO exhibited non-conservative mixing through the water column with depressed concentrations in the halocline (Fig. 3b).

The $\mathrm{pH}$ of the brackish portion of the cave water column was nearly constant at 6.9. The pH in the mixing zone dropped as low as 6.6 and then increased to a typical seawater value of 7.2 below the halocline (Fig. $2 d$ ). When salinity was plotted against $\mathrm{pH}$, it was evident that mixing was non-conservative due to hydrogen ion production in the halocline (Fig 3c).

Methane and TDS in the cave waters were low. Two samples collected for methane in the halocline were 72 and $180 \mathrm{nM}$, while TDS was below the detection limit of $2 \mu \mathrm{M}$ throughout the water column.

\section{Organic carbon composition of sediments}

The percentage of organic carbon in the sediments decreased dramatically with distance into the cave. At the cave entrance, where epilithic algae and vegetative detritus covered rock surfaces and the bottom of the pool, the sediments were rich with organic carbon. The percent organic carbon at the cave entrance ranged from 1.9 to $24.4 \%(n=4)$. In the twilight zone

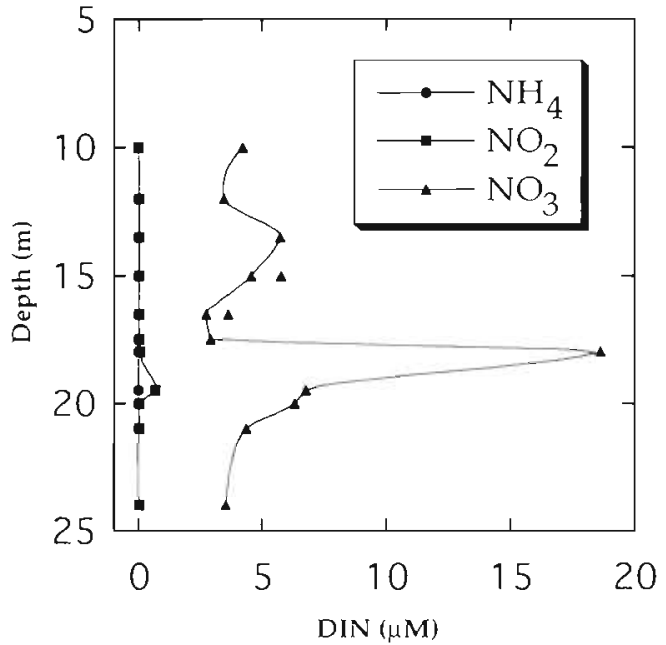

Fig. 5. Vertical profile of dissolved inorganic nitrogen (DIN) from Mayan Blue cave system. August 1994. Nitrate and nitrite peaks occurred in the halocline

(defined as $<60 \mathrm{~m}$ from the entrance), however, the amount of organic carbon in the sediments dropped dramatically. Organic carbon in these sediments ranged between 0.1 and $4.3 \%(n=8)$. The sediments in the dark portion of the cave (defined as $>60 \mathrm{~m}$ from the cave entrance) where the troglobites reside contained even less organic carbon. In this ared, organic carbon ranged from 0.1 to $1.9 \%(n=12)$. Sediments in the dark portion of the cave consisted almost entirely of calcium carbonate.

\section{Stable carbon and nitrogen isotopes of the organic reservoirs}

Forest. Fresh leaves collected from the forest floor had mean $\delta^{13} \mathrm{C}$ and $\delta^{15} \mathrm{~N}$ values of $-27.8 \pm 0.9(\mathrm{n}=8)$ and $+2.2 \pm 0.9(n=8)$, respectively (Table 1$)$. These values are typical of C-3 plant tissues (Boutton 1991, Nadelhoffer \& Fry 1994) and, as would be expected, were nearly identical to the stable isotope values for

Table 1. Stable carbon and nitrogen isotope data ( $\pm 1 \mathrm{SD}$ ) from the organic carbon reservoirs of the forest, cenote and cave at the Mayan Blue site. PPOM and SPOM: pool and soil particulate organic matter; $\mathrm{CBOM}$ : cave benthic organic matter

\begin{tabular}{|llcrcr|}
\hline Location & Source & $\delta^{13} \mathrm{C}$ & $\mathrm{n}$ & $\delta^{15} \mathrm{~N}$ & $\mathrm{n}$ \\
\hline Forest & Vegetation & $-27.8 \pm 0.9$ & 8 & $2.2 \pm 0.9$ & 8 \\
Forest & Soil & $-27.8 \pm 0.4$ & 8 & $2.2 \pm 0.8$ & 8 \\
Cenote & PPOM & $-35.3 \pm 2.0$ & 4 & $6.7 \pm 0.3$ & 4 \\
Cave & SPOM & $-24.1 \pm 2.0$ & 7 & $8.1 \pm 1.8$ & 6 \\
Cave & CBOM & $-24.1 \pm 6.0$ & 10 & $7.8 \pm 0.6$ & 9 \\
\hline
\end{tabular}


the soil. $\delta^{13} \mathrm{C}$ and $\delta^{15} \mathrm{~N}$ of the soil collected from the forest floor around the Mayan Blue study site averaged $-27.8 \pm 0.4(n=8)$ and $+2.2 \pm 0.8(n=8)$, respectively. The soil samples were separated into different size fractions $(<125 \mu \mathrm{m}$ and 125 to $500 \mu \mathrm{m})$ to examine possible isotopic differences between the size classes, but none were found $(t$-test, $p<0.01)$.

Pool particulate organic matter (PPOM). The living and non-living suspended material from the cenote that enters the cave is collectively referred to as PPOM to represent a single surrogate product of the cenote pool. PPOM had $\delta^{13} \mathrm{C}$ and $\delta^{15} \mathrm{~N}$ values of $-35.3 \pm 2.0$ $(\mathrm{n}=4)$ and $+6.7 \pm 0.3(\mathrm{n}=4)$, respectively (Table 1 ). Similar $\delta^{13} \mathrm{C}$ values for POM have been reported from aquatic systems where the vegetation and phytoplankton assimilate isotopically light biogenic $\mathrm{CO}_{2}$ (Rau 1978, Boutton 1991).

Soil particulate organic matter (SPOM). Although water in the cenote pool flows into the cave, the $\delta^{13} \mathrm{C}$ of the cave POM was drastically different from that found in the pool. Cave POM had a $\delta^{13} \mathrm{C}$ of $-24.1 \pm 2.0(\mathrm{n}=7)$ through the entire water column (Table 1). This material is classified as soil particulate organic matter (SPOM) because the forest soil, which has a similar $\delta^{13} \mathrm{C}$ of -27.8 , is most likely the primary source for SPOM. The discrepancy of $3.7 \%$ between the two can be attributed to enrichment of "' $\mathrm{C}$ that occurs during soil degradation (Boutton 1991). As soil degrades, it also becomes enriched with the heavier ${ }^{15} \mathrm{~N}$ isotope (Nadelhoffer \& Fry 1994). For that reason, the SPOM. with $\delta^{15} \mathrm{~N}$ of $+8.1 \pm 1.8(\mathrm{n}=6)$, is heavier with respect to nitrogen than the soil organic matter $(+2.2 \pm 0.8)$
Cave benthic organic matter (CBOM). Sedimentary organic matter from the cave, hereafter referred to as CBOM, had $\delta^{13} \mathrm{C}$ and $\delta^{15} \mathrm{~N}$ values of $-24.1 \pm 6.0(\mathrm{n}=10)$ and $+7.8 \pm 0.6(n=9)$, respectively (Table 1$)$. Because these values are nearly identical to its source, SPOM, it is presumed that SPOM sinks to the sediment and becomes CBOM.

Troglobitic fauna. The carbon and nitrogen stable isotope values of the troglobitic fauna displayed a wide range of values (Table 2). Carbon stable isotope values ranged between -21.2 and $-42.6 \%$, while the nitrogen stable isotope values ranged between +4.1 and $+13.4 \%$.

\section{DISCUSSION}

\section{Nitrification and carbon cycling in anchialine caves}

Our initial hypothesis was that soil from the forest, particulate matter in the pool and particulate matter from the Caribbean Sea would support the anchialine ecosystem, but upon closer inspection we found that production of organic matter by chemoautotrophic bacteria could be a significant food component. The presence of the small nitrite peak and dramatic nitrate peak in the mixing layer that coincided with a DO minimum (Fig. 5) suggests that nitrification is occurring. Nitrification is a chemoautotrophic process whereby ammonium $\left(\mathrm{NH}_{4}{ }^{+}\right)$is sequentially oxidized, first to nitrite $\left(\mathrm{NO}_{2}{ }^{-}\right)$and then nitrate $\left(\mathrm{NO}_{3}{ }^{-}\right)$. Nitrification is a common microbial event in aphotic oceanic environ-

Table 2. Taxonomy, habitat ( $A$ : above halocline, pelagic; $B$ : below halocline, pelagic; $C$ : euryhaline, benthic) and stable isotope data for the troglobites sampled

\begin{tabular}{|c|c|c|c|c|c|c|c|}
\hline Organism & Habitat & $\delta^{13} \mathrm{C}$ & $\mathrm{SD}$ & $\mathrm{n}$ & $\delta^{15} \mathrm{~N}$ & SD & $\mathrm{n}$ \\
\hline \multicolumn{8}{|l|}{ Crustacea } \\
\hline \multicolumn{8}{|l|}{ Decapoda } \\
\hline Typhlatya mitchelli & A & -36.1 & 5.2 & 10 & 9.1 & 1.7 & 10 \\
\hline Creaseria morley 1 & A & -36.3 & 4.2 & 4 & 11.7 & 2.1 & 2 \\
\hline \multicolumn{8}{|l|}{ Amphipoda } \\
\hline Hadziidae & A & -31.0 & 4.1 & 15 & 13.1 & 1.3 & 10 \\
\hline \multicolumn{8}{|l|}{ Thermosbaenacea } \\
\hline Tulumella unidens & $A$ & -34.1 & 4.9 & 9 & 8.4 & 2.6 & 7 \\
\hline \multicolumn{8}{|l|}{ Mysidacea } \\
\hline Antromysis cenotensis & A & -30.7 & 2.5 & 4 & 10.1 & 1.1 & 4 \\
\hline \multicolumn{8}{|l|}{ Remipedia } \\
\hline Speleonectes tulumensis & $\mathrm{B}$ & -31.1 & 4.2 & 3 & 11.7 & 0.4 & 2 \\
\hline \multicolumn{8}{|l|}{ Isopoda } \\
\hline Cirolanidae & $\mathrm{C}$ & -27.5 & 0.4 & 2 & 105 & - & 1 \\
\hline \multicolumn{8}{|l|}{ Teleostomi } \\
\hline \multicolumn{8}{|l|}{ Ophidiiformes } \\
\hline Ogilbea pearsei & $A$ & -30.7 & - & 1 & 13.3 & - & 1 \\
\hline
\end{tabular}


ments where DO is low (Gundersen 1966, Carlucci \& McNally 1969). Both of these environmental conditions exist in anchialine cave systems. Because nitrate production is believed to be strictly biogenic (Ward 1986), the presence of nitrate in the mixing zone of the cave water column can only be explained by nitrification.

The role of nitrification in the ocean is important for nitrogen cycling, but has generally been considered unimportant as a food source. Unusually high rates of nitrification at intermediate salinities in the mixing region of the Mississippi River (USA) plume have been reported (Pakulski et al. 1995), but nitrification as a mechanism for carbon fixation is inefficient. The ratio of carbon fixed to ammonium oxidized varies from 0.07 to 0.18 (Feliatra \& Bianchi 1993). Consequently, the contribution of nitrifying bacteria to the total organic pool of the Mississippi River plume is most likely small even though the rates of nitrification are high. However, in anchialine systems, where organic matter is in short supply, production considered insignificant in other ecosystems could prove substantial

Chemoautotrophic nitrification in anchialine caves can be likened to 'old' production in oceanic systems where remineralized nitrogen is recycled by the phytoplankton. Excretion by troglobitic metazoans, transformation of organic matter by bacteria and ammonification by heterotrophic microbes are the likely sources of ammonia supporting the nitrifiers. The pulse of hydrogen ions at the halocline indicates that such heterotrophic activity occurred (Fig. 2d)

A model for carbon cycling that includes nitrification is presented in Fig. 6. The 2 unequivocal sources of organic matter available for the anchialine food web were SPOM and PPOM. The source of SPOM was forest soil that percolated into the system through the cracks and fissures of the limestone bedrock. Its presence was corroborated by the similarity of the stable carbon isotope signatures between the POM collected in the cave and the surface soils collected from the forest. PPOM must have entered the ecosystem as water from the cenote flowed into the cave. Although the PPOM isotope signature was not reflected in the cave POM, it was observed in some of the troglobitic species.

The similarity between the cave POM and the forest soil does not preclude the presence of PPOM as a food source in the cave. Although the SPOM overwhelmed the isotopic signature of the PPOM in the cave POM, it is entirely possible that the pelagic crustaceans selectively fed on the less abundant PPOM fraction. Del Giorgio \& France (1996) proposed this as a mechanism to explain the differences in the isotopic signature of the zooplankton and bulk POM of numerous freshwater and marine environments. PPOM is primarily algae, which has a higher proportion of nitrogen than vascular plants. Thus, it makes sense that the fauna would preferentially consume the PPOM despite the fact that it is present in small quantities.

The unusually light $\delta^{13} \mathrm{C}$ of the fauna provides additional evidence that nitrifying bacteria may be present in the caves. Peterson et al. (1980) reported that nitrifying bacteria are -28 to $-30 \%$ lighter than their carbon source. Given the -11 to $-15 \%$ range of DIC measured in the mixing zone where the nitrate peak was observed (Fig. 4b), one would expect that their stable carbon isotope values of the nitrifying bacteria would range somewhere between -35 and $-45 \%$. $\delta^{13} \mathrm{C}$ values in this range were measured in the troglobitic fauna. Individuals from the atyid shrimp species Typhlatya mitchelli $(-42.4 \%)$ and the thermosbaenacean species Tulumella unidens $(-42.6 \%$ ) were more negative than any of the POM samples we measured, and are more negative than what one would expect from algae in the cenote. The lightest $\delta^{13} \mathrm{C}$ POM value from the pool was $-38.3 \%$. This value fits into the range of -33 to $-38 \%$ that one would expect for pure algae utilizing the pool DIC (Peterson \& Fry 1987). Recognizing that there is an enrichment in stable carbon isotope values of about $1 \%$ per trophic level transfer (Haines \& Montague

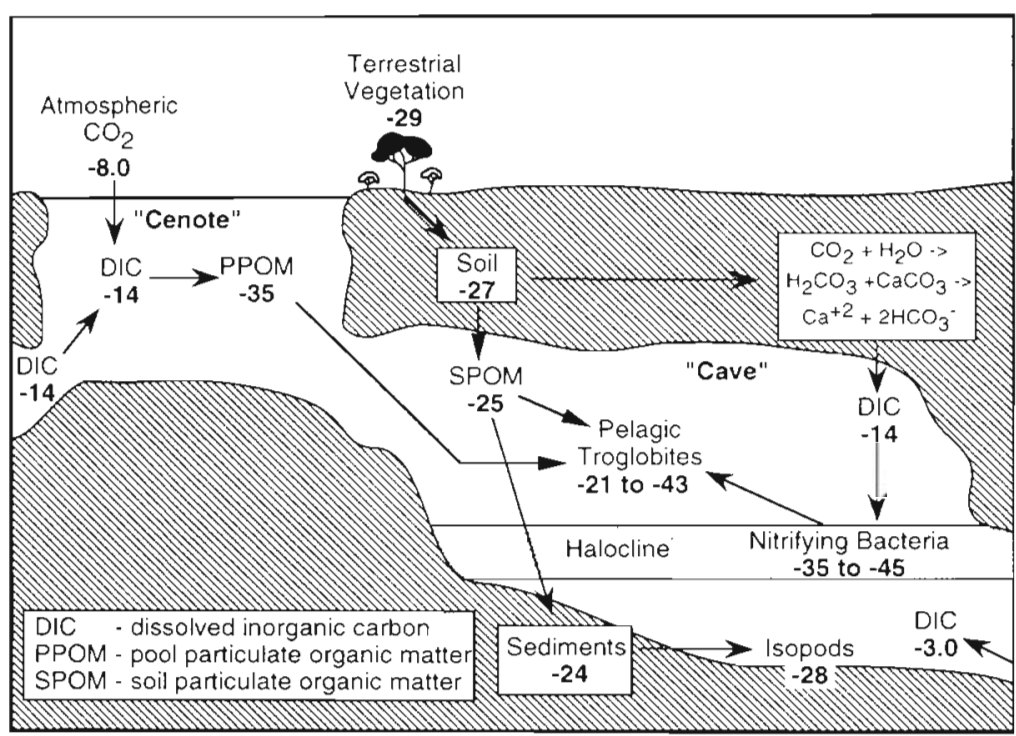

Fig. 6. Model for carbon cycling into and within the anchialine ecosystem. The pelagic troglobites consist of all crustaceans and fish living in the water column of the cave. Numbers represent measured or estimated $\delta{ }^{13} \mathrm{C}$ ranges for that compartment 

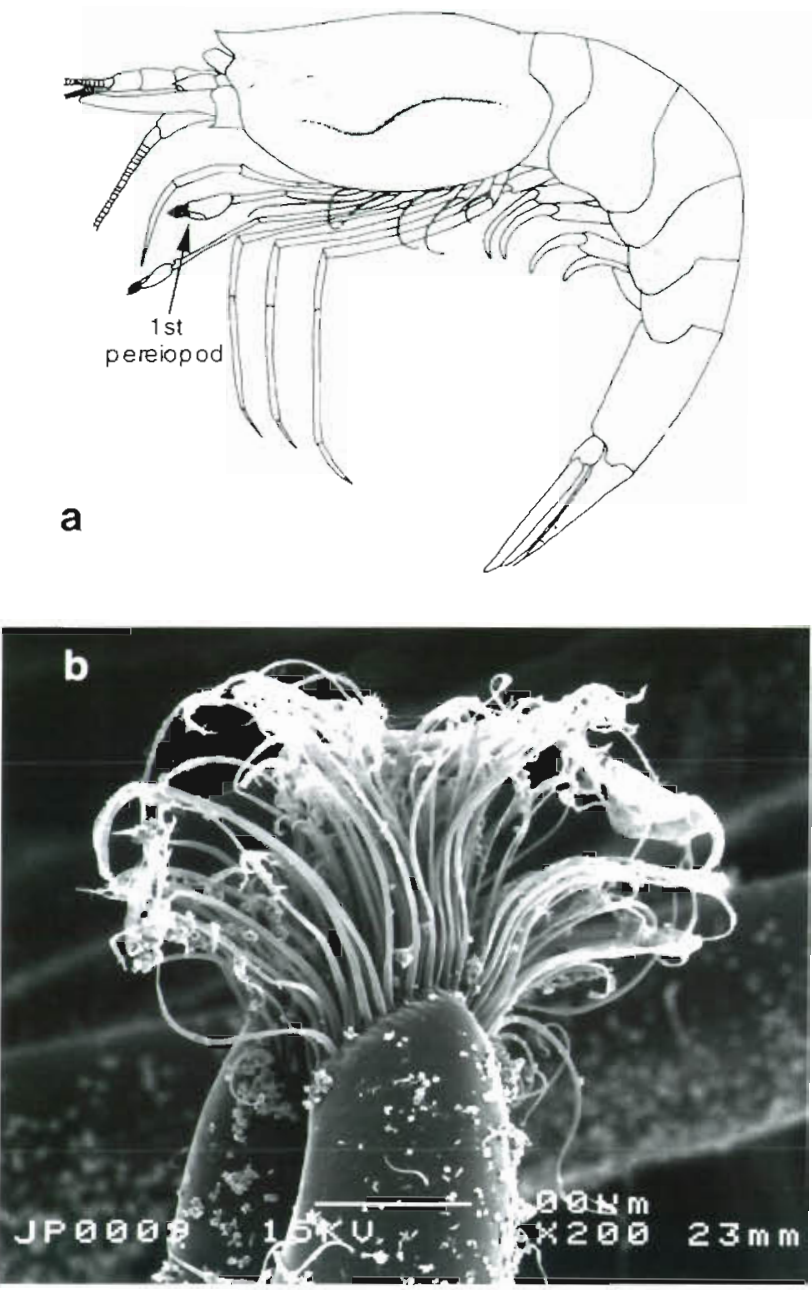

Fig 7 Typhlatya mitchelli. (a) Lateral view (Hobbs et al. 1.977); (b) electron micrograph of first pereiopod, an appendage used for filter feeding (scale bar is $100 \mu \mathrm{m}$ )

1979), the values measured from individual. T. mitchelli and $T$. unidens are impossible to obtain if the only food sources were SPOM and PPOM. These individuals must have been supplementing their diet with a ${ }^{13} \mathrm{C}$ depleted source of organic carbon.

The variability in stable carbon isotope values of the suspension-feeding, pelagic crustacean species may be explained by specialized feeding behavior Typhlatya mitchelli and Tulumella unidens employ specialized feeding mechanisms that should enable them to graze small algal cells and bacteria, particularly nitrifying bacteria. which can be as large as $3 \mu \mathrm{m}$ (Ward 1986). I mitchelli has setal tufts on its first and second pereiopods that allow it to 'sweep' minute particles from the water (Fig 7). The individual setae have an array of filaments and saw-like structures that could ensnare and entangle bacteria or other small algal particles. Likewise, T. unidens has highly setose maxil- lules that also should allow it to gather small particles although less effectively than $T$ mitchelli $(M$. Wicksten pers comm.). On the other hand, mysids use their thoracic endopods to collect larger food particles (Shram 1986). Assuming that the soil particles are larger than the bacteria and algae, the ability to select differently sized food particles that are isotopically distinct may explain the differences in the stable carbon isotope signatures of the 3 suspension-feeding crustacean species.

Methanotrophic and sulfide-oxidizing bacteria may also be significant food sources. Groundwater methanotrophic bacteria have extremely light $\delta^{13} \mathrm{C}$, ranging between -55 to $-90 \%$ when oxidizing biogenic methane (Grossman \& Coffman 1989), while sulfide-oxidizing bacteria from a nearby sinkhole, Cenote Angelita, had a $\delta^{13} \mathrm{C}$ of $-34.3 \%$. Assimilation of these ${ }^{13} \mathrm{C}$ depleted stable carbon isotope sources could help explain the faunal isotope ratios. Concentrations of both methane and sulfide in the Mayan Blue system were low (see 'Results'), but low concentrations of these compounds can support chemoautotrophic production by methanotrophic and sulfide-oxidizing bacteria (Dando et al. 1985, Ward \& Kilpatrick 1990).

Contrary to our original hypothesis, coastal-borne POM appears to be a negligible source of organic food for the organisms in the Mayan Blue cave system. A POM sample collected in the seawater portion of that cave had a. $\delta^{13} \mathrm{C}$ of $-24.3 \%$. This value is nearly identical to the mean $\delta^{13} \mathrm{C}$ of POM from the upper cave waters $(-24.7)$ and is within the range reported for marine waters $(-22.0$ to -24.4$)$ by Williams \& Gordon (1970). This similarity between the seawater POM and soil POM makes it difficult to surmise the origin of the POM in the seawater of the cave. However, due to the proximity of the overlying soil horizon and the $6 \mathrm{~km}$ distance of the Mayan Blue cave system from the coast, we believe the POM in the seawater portion of this cave is derived principally from the soil. We still believe cave systems closer to the coast, which have a more recent input of coastal seawater, will contain a larger reservoir of marine-derived particulates for the euhaline troglobitic community. However, in systems far trom the coast like Systema Naranjal, the marine influence is slight. The dearth of organic matter in the cave seawater in caves around Mayan Blue accounts for the fact that near-microscopic ostracods are the largest consumers of particulates below the halocline.

\section{Trophic structure of the food web}

A dual isotope approach was used to resolve the relative contributions of the measured organic sources to each species and to define the trophic structure of the 
food web (Fig. 8). Based on a 2 to $3 \%$ increase in $\delta^{15} \mathrm{~N}$ per trophic level transfer between consumer and consumed (DeNiro \& Epstein 1981), there appear to be 2.0 to 2.5 trophic levels in the food web. Typhlatya mitchelli, Tulumella unidens, Antromysis cenotensis (a mysid) and isopods constitute the lower trophic level and show source feeding preferences that agree with those suggested by the stable carbon isotope data. $T$. mitchelli and $T$ unidens were 2.4 and $1.7 \%$ heavier, respectively, than the PPOM with regard to nitrogen, while similar with regard to carbon. These relationships suggest a strong, but not complete, dependence on PPOM. Large standard deviations of the stable isotope data for the T. mitchelli and T. unidens populations (Table 2) attest to the flexibility of these species to feed on SPOM and nitrifying bacteria, along with PPOM. A. cenotensis is intermediate between PPOM and SPOM in terms of its stable carbon isotope values and is slightly heavier in nitrogen than some of the other pelagic crustaceans. Both trends suggest that the mysid $A$. cenotensis relies more so on SPOM. The isopods occupy the benthos and thus are reflective of the CBOM (Fig. 6).

The upper trophic level members - amphipods, the remipede Speleonectes tulumensis, the shrimp Creaseria morleyi and the blind cave fish Ogilbea pearsei-are all predators and/or scavengers, so their high trophic level ranking is expected. The $\delta^{15} \mathrm{~N}$ values of the amphipods and $O$. pearsei are the most positive Therefore, they are placed half a trophic level higher than S. tulumensis and C. morleyi since they are able to feed on members of both the same and lower trophic levels. Amphipods have been observed scavenging on the exuviae of other crustaceans (possibly even other amphipods), while $O$. pearsei is the top predator. $S$ tulumensis, a crustacean from the ancient class Remipedia, is the lone predator/scavenger in the seawater It is presumed to have fed on ostracods and crus taceans that have passed through the halocline.

\section{Comparison with the ecology of other anchialine caves of the Caribbean}

Similarities in habitat and community structure with other anchialine caves in the Caribbean suggest that our observations may not be site specific. For instance, salinity, DO and temperature profiles reported from an anchialine cave in Cuba (Cueva de los Carboneros) by Yager (1994) resemble those from Mayan Blue and other anchialine caves we investigated in the Yucatan. As well, sites in the Bahamas, the Dominican Republic and Cuba share 4 common genera of Crustacea with those found in the Yucatan Peninsula (Holsinger 1989). Investigations in other cave systems and continued research in Systema Naranjal will provide a more complete understanding of the fundamental biogeochemical forces that drive anchialine cave ecology. The system model presented in this paper is certain to be altered and improved as important factors we have not yet considered are examined, and spatial and temporal patterns are more closely considered. Finally, the stability of anchialine cave systems makes them suitable models for studying the dynamics of other oligotrophic ecosystems.

Acknowledgements. The authors thank the following individuals for their creative, logistical and laboratory assistance: Mike Madden, Jim Coke, Elva Escobar, Javier Alcocer, Brett Dodson, Thomas Boutton, John Morse, Mary Wicksten, Jeff Chanton, Lynn Roelke, Rody Best, Rick Coffin and Cheryl Kelley. This study was supported by grants from the EPA (CR 820669), The Texas Institute of Oceanography, Texas A\&M University at Galveston. The Richmond Area Speleological Society and The Cave Research Foundation. 


\section{LITERATURE CITED}

Aminot A, Kerovel R (1982) Dosage automatique de l'uree dans l'eau de mar: une methode très sensible à la diacétylmonoxine. Can J Fish Aquat Sci 39:174-183

Back W. Hanshaw BB (1974) Hydrogeochemistry of the northern Yucatan Peninsula, Mexico with a section on Mayan water practices. In: Weidie AE (ed) Field seminar on water and carbonate rocks of the Yucatan Peninsula, Mexico. New Orleans Geological Society, New Orleans, p 45-77

Back W, Hanshaw BB, Herman JS, Van Driel JN (1986) Differential dissolution of a Pleistocene reef in the ground water mixing zone of coastal Yucatin, Mexico. Geology 43:137-140

Back W, Hanshaw BB, Pyle TE, Plummer NN, Weide AE (1979) Crochemical significance of groundwater discharge and carbonate dissolution to the formation of Caleta Xel Ha, Quintana Roo, Mexico. Water Resour Res 15:1521-1535

Boutton TW (1991) Stable carbon isotope ratios of natural materials: II. Atmospheric, terrestrial, marine, and freshwater environments. In: Coleman DC, Fry B (eds) Carbon isotope techniques. Academic Press, New York, p 173-185

Bowman TE, Garner SP, Hessler RR, Ilıffe TM, Sanders HL (1985) Mictacea, a new order of Crustacea Peracarida. J Crustac Brol 5:74-78

Carlucci AF, MCNally PM (1969) Nitrification by marine bacteria in low concentrations of substrate and oxygen. Limnol Oceanogr 14:736-739

Cline JD (1969) Spectrophotometnc determination of hydrogen sulfide in natural waters. Limnol Oceanogr 14 $454-458$

Dando PR, Southward AJ, Southward EC, Terwilliger NB, Terwilliger RC (1985) Sulfur-oxidizing bacteria and haemoglobin in the gills of the bivalve mollusc Myrtea spinifera. Mar Ecol Prog Ser 23:85-98

Del Giorgio PA, France RL (1996) Ecosystem-specific patterns in the relationship between zooplankton and POM or microplankton $\delta^{13} \mathrm{C}$. Limnol Oceanogr 41:359-365

DeNiro MJ, Epstein S (1981) Influence of diet on the distribution of nitrogen isotopes in animals. Geochim Cosmochim Acta 45:341-351

Dickson AG, Goyet C (1991) Handbook of methods for the analysis of various parameters of the $\mathrm{CO}_{2}$ system in the sea. US Dept of Energy, Washington, DC

Dickson GW (1975) A preliminary study of heterotrophic microrganisms as factors in substrate selection of troglobitic invertebrates. NSS Bull 37:89-93

Feliatra F, Bianchi M (1993) Rates of nitrification and carbon uptake in the Rhone River plume (Northwest Mediterranean Sea). Microb Ecol 26:21-28

Fichez R (1991) Suspended particulate organic matter in a Mediterranean submarine cave. Mar Biol 108:167-174

Grossman EL, Coffman BK (1989) Bacterial production of methane and its influence on ground-water chemistry in east-central Texas aquifers. Geology 17:495-499

Gundersen K (1966) The growth and respiration of Nitrosocystis oceanus at different partial pressures of oxygen J Gen Microbiol 42:387-396

Haines E. Montague C (1979) Food sources of estuarine invertebrates analyzed using ${ }^{13} \mathrm{C}^{12} \mathrm{C}$ ratios. Ecology 60:48-56

Hart CW JT, Manning RB, Iluffe TM (1985) The fauna of Atlantic marine caves: evidence of dispersal whlle maintaining ties to deep water. Proc Biol Soc Wash 98:288-292

Hobbs HH Jr, Hobbs HH. III, Daniel MA (1977) A review of the troglobitic decapod crustaceans of the Americas. Smithson Contrib Zool 244:1-183
Holsinger JR (1989) A preliminary zoogeographıc analysis of five groups of crustaceans from anchualine caves in the West Indian region. Proc 10th Int Congr Speleol 1:25-26

liffe TM (1983) Biogeography and the caves of Bermuda. Nature 302:141-1.42

[luffe TM (1992a) Anchialıne cave bılogy. In: Camacho Al (ed) The natural history of biospeleology. Museo Nacional De Clencias Naturales, Madrid, p 615-636

Iliffe TM (1992b) An annotated list of the troglobitic anchialine and freshwater fauna of Quintana Roo. In: Navarro D. Suarez-Morales E (eds) Diversidad biologica en la reserva de la biosfera de Sian Ka'an Quintana, Roo, Mexico. (:IQRO/SEDESOL, Chetumol, p 197-213

Iliffe TM, Jickells TD, Brewer MS (1984a) Organic pollution of an inland marine cave from Bermuda. Mar Environ Res 12 . $173-189$

Uliffe TM, Wilkens H, Parzefall J. Williams D (1984b) Marine lava cave fauna: composition, biogeography and origins. Science 225:309-311

Kornicker LS, Iliffe TM (1989) New Ostracoda (Halocyprida Thaumatocyprididae and Halocyprididae) from anchialine caves in the Bahamas, Palau and Mexico. Smithson Contrib Zool 470:1-47

Koraleff F (1970) Revised version of 'Direct determination of ammonia in natural waters using indephenol blue. Int Con. Explor. Sea, C.M. 1969/C.9.' ICES, Information on techniques and methods for seawater analysis. Interlab Report No. 3:19-22

Macko SA (1981) Stable nitrogen isotopes as tracers of organic geochemical processes. PhD thesis, University of Texas at Austin

Manning RB, Hart CW Jr, Iliffe TM (1986) Mesozoic relicts in marine caves of Bermuda. Stygologia 2:156-166

McAuliffe C (1971) Gas chromatographic determination of solutes by multiple phase equilibrium. Chemtech 1:46-51

Nadelhoffer KJ, Fry B (1994) Nitrogen isotope studies in forest ecosystems. In: Lajtha $\mathrm{K}$, Michener RH (eds) Stable 1sotopes in ecology and environmental science. Blackwell Scientific Publications, London, p 22-44

Nieuwenhuize J, Maas YEM, Middelburg JJ (1994) Rapid analysis of organic carbon and nitrogen in particulate materials. Mar Chem 45:217-224

Pakulski JD, Benner R, Amon R, Eadie B, Whitledge T (1995) Community metabolism and nutrient cycling in the Mississippi River plume: evidence for intense nitrification at intermediate salinities. Mar Ecol Prog Ser 117:207-218

Peterson BJ, Fry B (1987) Stable 1sotopes in ecosystem studies. Annu Rev Ecol Syst 18:293-320

Peterson BJ, Howarth RW, Lipschultz F, Ashendorf D (1980) Sait marsh defritus: an alternative interpretation of stable carbon isolope ratios and the fate of Spartina alterniflora. Oikos 34:173-177

Pohlman J (1995) Analysis of the ecology of anchialine caves using carbon and nitrogen stable isotopes. MSc thesis, Texas A\&M University, College Station

Rau G (1978) Carbon-13 depletion in a subalpine lake: carbon flow implications. Science 201:901-902

Roughgarden J (1974) Niche width: biogeographic patterns among Anolis lizard populations. Am Nat 108:429-442

Sarbu SM, Kane TC. Kincle BK (1.996) A chemoautotrophically based cave ecosystem. Science 272:1953-1955

Shram FR (1986) Crustacea. Oxford University Press, Oxford

Southward AJ, Kennicutt MC II, Alcala Herrera J, Abbıatı M, Airoldi L, Cinelli F, Branchi CN, Morri C, Southward EC (1996) On the biology of submarine caves with sulfur spnngs: appraisal of $13 \mathrm{C} / 12 \mathrm{C}$ ratios as a gulde to trophic relations. J Mar Biol Assoc UK 76:265-285 
Stoessell RK, Ward WC, Ford BH, Schuffert JD (1989) Water chemistry and $\mathrm{CaCO}_{3}$ dissolution in the saline part of an open-flow mixing zone, coastal Yucatan Peninsula, Mexico. Geol Soc Amer Bull 101:159-169

Ward BB (1986) Nitrification in marine environments. In: JJ Prosser (ed) Nitrification. IRL Press, Oxford, p 157-184

Ward BB, Kilpatrick KA (1990) Relationship between substrate level concentration and oxidation of ammonium and methane in a stratified water column. Cont Shelf Res 10 $1193-1208$

This article was submitted to the editor
Williams PM, Gordon LI (1970) Carbon 13:carbon 12 ratios in dissolved and particulate organic matter in the sea. Deep Sea Res 17:19-27

Yager J (1981) Remipedia, a new class of Crustacea from a marine cave in the Bahamas. J Crustac Biol 1. $328-333$

Yager J (1994) Speleonectes gironensis, new species (Remipedia: Speleonectidae), from anchialine caves in Cuba, with remarks on biogeography and ecology. J Crustac Biol $14: 752-762$

Manuscript received: February 3, 1997

Revised version accepted: June 20,1997 